interactions significantly shorter than van der Waals distances. The result is essentially an independent ion-pair group with the conformation determined mainly by intramolecular forces and packing.

SHS and SBL thank the Robert A. Welch Foundation (F-017) for its generous support of the crystallographic investigation of this research. Financial support for JSB by the National Science Foundation (CHE$800059)$ is also gratefully acknowledged.

\section{References}

Bandy, J. A., Truter, M. R. \& Vögtle, F. (1981). Acta Cryst. B37, 1568-1571.

Bradshaw, J. S., Baxter, S. L., Lamb, J. D., Izatt, R. M. \& Christensen, J. J. (1981). J. Am. Chem. Soc. 103, $1821-1827$.

Dalley, N. K. \& Larson, S. B. (1979a). Acta Crist. B35, 1901-1903.
Dalley, N. K. \& Larson, S. B. (1979b). Acta Cryst. B35, 2428-2430.

Dunitz, J. D., Dobler, M., Seiler, P. \& Phizackerley, R. P. (1974). Acta Cryst. B30, 2733-2738.

Hamilton, W. C. \& Ibers, J. A. (1968). Hydrogen Bonding in Solids: Methods of Molecular Structure Determination. New York: Benjamin.

International Tables for X-ray Crystallography (1974). Vol. IV. Birmingham: Kynoch Press.

JoHnson, C. K. (1965). ORTEP. Report ORNL-3794. Oak Ridge National Laboratory, Tennessee.

Main, P., Hull, S. E., Lessinger, L., Germain, G., DeClerCQ, J. P. \& WoOlfSon, M. M. (1978). MULTAN 78. A System of Computer Programs for the Automatic Solution of Crystal Structures from X-ray Diffraction Data. Univs. of York, England, and Louvain, Belgium.

Maverick, E., Grossenbacher, L. \& Trueblood, K. N. (1979). Acta Cryst. B35, 2233-2237.

Stewart, R. F., Davidson, E. R. \& Simpson, W. T. (1965). J. Chem. Phys. 42, 3175-3187.

Acta Cryst. (1982). B38, 1862-1864

\title{
S-tert-Butylthiouronium Perchlorate-1,4,7,10,13,16-Hexaoxacyclooctadecane (2:1)
}

\author{
By J. W. H. M. UiterwiJk, S. HARKema and G. J. van Hummel \\ Chemical Physics Laboratory, Twente University of Technology, PO Box 217, 7500 AE Enschede, \\ The Netherlands \\ AND J. GeEvers and D. N. Reinhoudt \\ Organic Chemistry Laboratory, Twente University of Technology, PO Box 217, 7500 AE Enschede, \\ The Netherlands
}

(Received 18 September 1981; accepted 8 February 1982)

\begin{abstract}
C}_{12} \mathrm{H}_{24} \mathrm{O}_{6} \cdot 2 \mathrm{C}_{5} \mathrm{H}_{13} \mathrm{~N}_{2} \mathrm{~S}^{+} \cdot 2 \mathrm{ClO}_{4}^{-}, \quad M_{r}=$ 729.70, triclinic, $P \overline{1}, a=10.905(3), b=10.722$ (4), $c=9.329(5) \AA, \alpha=111.41(3), \beta=98.47(2), \gamma=$ $110.40(2)^{\circ}, V=903.48 \AA^{3}, Z=1, D_{c}=1.34 \mathrm{~g} \mathrm{~cm}^{-3}$, $\mu=0.36 \mathrm{~cm}^{-1}$. The crystal structure was solved by direct methods. All $\mathrm{H}$ atoms have been located. $R_{w}=$ $4.6 \%$ for 2524 observed reflexions. The macrocyclic ring has approximate $D_{3 d}$ symmetry. One of the $\mathrm{NH}_{2}$ groups is hydrogen-bonded to the ring, the other $\mathrm{NH}_{2}$ group forms hydrogen bonds to two perchlorate ions.
\end{abstract}

Introduction. As shown already by Pedersen (1971) macrocyclic polyethers are capable of forming stable crystalline complexes with organic and inorganic molecules and ions. As part of a project aimed at the synthesis of macrocyclic receptors for small urea-like molecules, we report here the crystal structure of a (2:1) complex of $S$-tert-butylthiouronium perchlorate

0567-7408/82/061862-03\$01.00 with 18 -crown-6 $\quad(1,4,7,10,13,16$-hexaoxacyclooctadecane) (BTPC).

BTPC $(2: 1)$ was prepared by extraction of an aqueous solution of $S$-tert-butylthiouronium chloride (4 $\mathrm{mmol})$ and lithium perchlorate $(4 \mathrm{mmol})$ with a solution of 18-crown-6 (1 mmol) in chloroform. The compound was precipitated by addition of diethyl ether and recrystallized from ethanol/petroleum ether.

A BTPC $(1: 1)$ complex can be obtained in a similar way by changing the ratio of the above mentioned compounds to $4: 1: 4$. Attempts to solve the crystal structure of the $(1: 1)$ complex were hampered by disorder in one of the two macrocyclic rings in the crystal structure at $150 \mathrm{~K}$.

Intensities for BTPC $(2: 1)$ were measured at room temperature with a Philips PW 1100 diffractometer (Mo $K \alpha$ radiation, graphite monochromator). Reflexions up to $\theta=25^{\circ}$ were measured in the $\theta / 2 \theta$ scan

(C) 1982 International Union of Crystallography 
mode. The number of reflexions measured was 3383 , of which 2524 independent reflexions had $I>\sigma(I)$ and these were used in the solution and refinement of the structure. The structure was solved by MULTAN (Germain, Main \& Woolfson, 1971) and refined by full-matrix least squares with ORFLS (Busing, Martin \& Levy, 1962). The weight for each reflexion was taken to be $w=\left[\sigma\left(F_{o}\right)+0.01\left|F_{o}\right|\right]^{-2}$ where $\sigma\left(F_{o}\right)$ is the e.s.d. of the structure factor derived from counting statistics. Scattering factors were taken from International Tables for X-ray Crystallography (1974). For $\mathrm{H}$ the scattering factors of Stewart, Davidson \& Simpson (1965) were used. All $\mathrm{H}$ atoms were found in a difference Fourier synthesis. The final values of $R$ and $R_{w}$ were $4.8 \%$ and $4.6 \%$ respectively (total number of parameters refined: 300 ; scale factor, isotropic extinction parameter, position parameters, anisotropic thermal parameters for non- $\mathrm{H}$ atoms, isotropic thermal parameters for $\mathrm{H}){ }^{*}$ The asymmetric part of the unit cell contains one $S$-tert-butylthiouronium perchlorate molecule and one half of the 18-crown-6 ring. The other half is generated by a centre of symmetry.

Discussion. Final atomic positional parameters are given in Table 1. The numbering of the atoms is

* Lists of structure factors, anisotropic thermal parameters for the non- $\mathrm{H}$ atoms, positional and isotropic thermal parameters for the $\mathrm{H}$ atoms and complete lists of bond lengths and angles have been deposited with the British Library Lending Division as Supplementary Publication No. SUP 36725 (22 pp.). Copies may be obtained through The Executive Secretary, International Union of Crystallography, 5 Abbey Square, Chester CH1 2HU, England.

Table 1. Fractional coordinates $\left(\times 10^{4}\right)$ and equivalent isotropic thermal parameters $\left(\times 10^{3}\right)$ for non-H atoms

\begin{tabular}{lrrrr} 
& \multicolumn{1}{c}{$y$} & \multicolumn{1}{c}{$z$} & $U_{\text {eq }}{ }^{*}\left(\AA^{2}\right)$ \\
$\mathrm{C}(1)$ & $195(4)$ & $2350(5)$ & $4038(4)$ & $71(2)$ \\
$\mathrm{O}(2)$ & $269(2)$ & $2531(2)$ & $2613(2)$ & $61(1)$ \\
$\mathrm{C}(3)$ & $-511(4)$ & $3282(4)$ & $2301(4)$ & $66(2)$ \\
$\mathrm{C}(4)$ & $-405(4)$ & $3415(3)$ & $796(4)$ & $65(2)$ \\
$\mathrm{O}(5)$ & $-1008(2)$ & $1965(2)$ & $-530(2)$ & $58(1)$ \\
$\mathrm{C}(6)$ & $-936(4)$ & $1997(4)$ & $-2019(4)$ & $68(2)$ \\
$\mathrm{C}(7)$ & $-1523(4)$ & $450(4)$ & $-3333(4)$ & $68(2)$ \\
$\mathrm{O}(8)$ & $-626(2)$ & $-211(2)$ & $-3123(2)$ & $61(1)$ \\
$\mathrm{C}(9)$ & $-1105(4)$ & $-1678(4)$ & $-4382(4)$ & $68(2)$ \\
$\mathrm{S}(10)$ & $3451(1)$ & $659(1)$ & $-501(1)$ & $73(1)$ \\
$\mathrm{C}(11)$ & $2731(3)$ & $1679(3)$ & $724(3)$ & $55(1)$ \\
$\mathrm{N}(12)$ & $1433(3)$ & $1315(4)$ & $156(4)$ & $66(2)$ \\
$\mathrm{N}(13)$ & $3476(4)$ & $2759(4)$ & $2153(4)$ & $83(2)$ \\
$\mathrm{C}(14)$ & $4658(3)$ & $2018(3)$ & $-1019(4)$ & $62(2)$ \\
$\mathrm{C}(15)$ & $5027(7)$ & $1015(6)$ & $-2344(7)$ & $111(3)$ \\
$\mathrm{C}(16)$ & $3923(6)$ & $2747(7)$ & $-1666(7)$ & $93(3)$ \\
$\mathrm{C}(17)$ & $5916(4)$ & $3160(6)$ & $415(7)$ & $105(3)$ \\
$\mathrm{Cl}(18)$ & $6630(1)$ & $3624(1)$ & $5348(1)$ & $70(1)$ \\
$\mathrm{O}(19)$ & $6921(3)$ & $4360(3)$ & $7047(3)$ & $116(2)$ \\
$\mathrm{O}(20)$ & $7616(3)$ & $3111(4)$ & $5078(5)$ & $164(3)$ \\
$\mathrm{O}(21)$ & $6666(4)$ & $4687(4)$ & $4783(4)$ & $153(2)$ \\
$\mathrm{O}(22)$ & $5288(3)$ & $2445(3)$ & $4664(3)$ & $117(2)$
\end{tabular}

* Defined according to Willis \& Pryor (1975).

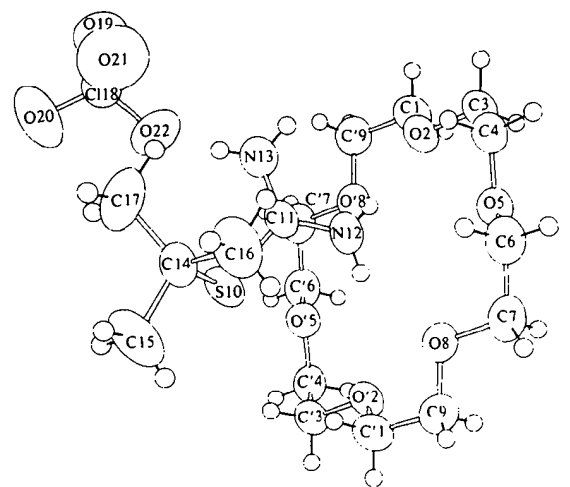

Fig. 1. Atomic numbering in BTPC. Primed atoms are related to the corresponding unprimed atoms by a centre of symmetry (the centrosymmetrically related $S$-tert-butylthiouronium perchlorate is not shown).
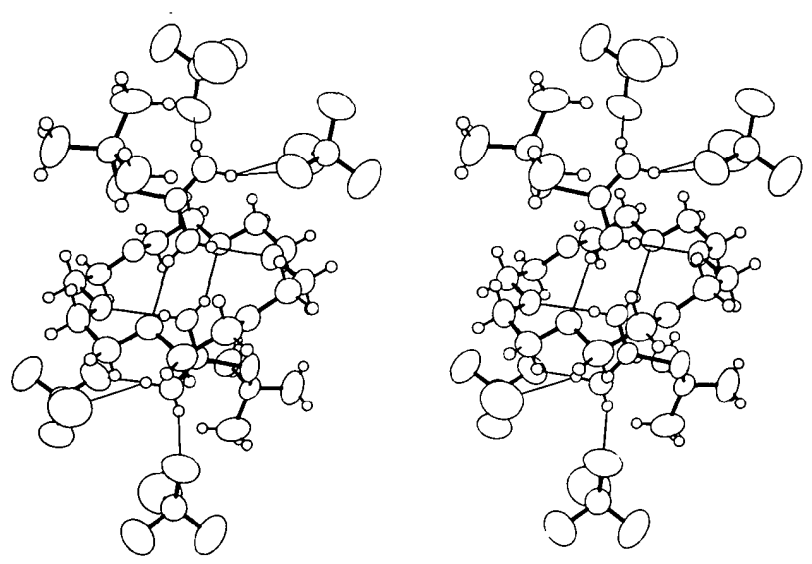

Fig. 2. Stereoscopic view of BTPC, showing the arrangement of hydrogen bonds (thin lines).

according to Fig. 1. Bond lengths and angles are shown in Table 2. Torsion angles in the macrocyclic ring are in Table 3. A stereoscopic view (Johnson, 1965) of the molecular complex is given in Fig. 2. From this figure it can be seen that one of the two $\mathrm{NH}_{2}$ groups is engaged in hydrogen bonding to two $\mathrm{O}$ atoms of the ring. The $\mathrm{N} \cdots \mathrm{O}$ distances and $\mathrm{N}-\mathrm{H} \cdots \mathrm{O}$ angles for these bonds are: $\mathrm{N}(12) \cdots \mathrm{O}(2) 2.898(5), \mathrm{N}(12) \cdots \mathrm{O}(8)$ 2.972 (5) $\AA ; \quad \mathrm{N}(12)-\mathrm{H}(12 B) \cdots \mathrm{O}(2) \quad 171(6)$, $\mathrm{N}(12)-\mathrm{H}(12 A) \cdots \mathrm{O}(8) 150(6)^{\circ}$. Contrary to the results for the related compound urea-18-crown-6 (5:1) (Harkema, van Hummel, Daasvatn \& Reinhoudt, 1981), the hydrogen bonding is not to neighbouring $O$ atoms in the macrocyclic ring, but to next nearest neighbours. The hydrogen-bonding scheme also differs from the one found in the complex of 18-crown-6 with benzenesulphonamide (1:2) (Knöchel, Kopf, Oehler \& Rudolph, 1978). In that complex the $\mathrm{NH}_{2}$ group is hydrogen-bonded to two opposite $\mathrm{O}$ atoms of the centrosymmetric ring. The second $\mathrm{NH}_{2}$ group is hydrogen-bonded to two perchlorate ions by 
Table 2. Bond distances $(\AA)$ and angles $\left(^{\circ}\right)$

$\begin{array}{lccc}\mathrm{C}(1)-\mathrm{O}(2) & 1.422(5) & \mathrm{S}(10)-\mathrm{C}(14) & 1.858(3) \\ \mathrm{O}(2)-\mathrm{C}(3) & 1.425(5) & \mathrm{C}(11)-\mathrm{N}(12) & 1.296(4) \\ \mathrm{C}(3)-\mathrm{C}(4) & 1.479(5) & \mathrm{C}(11)-\mathrm{N}(13) & 1.295(5) \\ \mathrm{C}(4)-\mathrm{O}(5) & 1.422(4) & \mathrm{C}(14)-\mathrm{C}(15) & 1.525(7) \\ \mathrm{O}(5)-\mathrm{C}(6) & 1.415(4) & \mathrm{C}(14)-\mathrm{C}(16) & 1.502(8) \\ \mathrm{C}(6)-\mathrm{C}(7) & 1.486(6) & \mathrm{C}(14)-\mathrm{C}(17) & 1.504(6) \\ \mathrm{C}(7)-\mathrm{O}(8) & 1.423(5) & \mathrm{Cl}(18)-\mathrm{O}(19) & 1.415(3) \\ \mathrm{O}(8)-\mathrm{C}(9) & 1.423(5) & \mathrm{Cl}(18)-\mathrm{O}(20) & 1.383(4) \\ \mathrm{C}(9)-\mathrm{C}^{\prime}(1) & 1.477(7) & \mathrm{Cl}(18)-\mathrm{O}(21) & 1.411(4) \\ \mathrm{S}(10)-\mathrm{C}(11) & 1.752(3) & \mathrm{Cl}(18)-\mathrm{O}(22) & 1.412(3) \\ & & & \\ \mathrm{C}^{\prime}(9)-\mathrm{C}(1)-\mathrm{O}(2) & 110 \cdot 0(3) & \mathrm{S}(10)-\mathrm{C}(14)-\mathrm{C}(15) & 101.9(3) \\ \mathrm{C}(1)-\mathrm{O}(2)-\mathrm{C}(3) & 112.0(3) & \mathrm{S}(10)-\mathrm{C}(14)-\mathrm{C}(16) & 109.8(4) \\ \mathrm{O}(2)-\mathrm{C}(3)-\mathrm{C}(4) & 109.2(3) & \mathrm{S}(10)-\mathrm{C}(14)-\mathrm{C}(17) & 111.6(3) \\ \mathrm{C}(3)-\mathrm{C}(4)-\mathrm{O}(5) & 109.0(3) & \mathrm{C}(15)-\mathrm{C}(14)-\mathrm{C}(16) & 111.0(5) \\ \mathrm{C}(4)-\mathrm{O}(5)-\mathrm{C}(6) & 112.5(3) & \mathrm{C}(15)-\mathrm{C}(14)-\mathrm{C}(17) & 111.1(5) \\ \mathrm{O}(5)-\mathrm{C}(6)-\mathrm{C}(7) & 109.6(3) & \mathrm{C}(16)-\mathrm{C}(14)-\mathrm{C}(17) & 111.1(5) \\ \mathrm{C}(6)-\mathrm{C}(7)-\mathrm{O}(8) & 109.7(3) & \mathrm{O}(19)-\mathrm{Cl}(18)-\mathrm{O}(20) & 107.1(3) \\ \mathrm{C}(7)-\mathrm{O}(8)-\mathrm{C}(9) & 112.4(3) & \mathrm{O}(19)-\mathrm{Cl}(18)-\mathrm{O}(21) & 106.1(2) \\ \mathrm{O}(8)-\mathrm{C}(9)-\mathrm{C}^{\prime}(1) & 110 \cdot 1(4) & \mathrm{O}(19)-\mathrm{Cl}(18)-\mathrm{O}(22) & 108.8(2) \\ \mathrm{C}(11)-\mathrm{S}(10)-\mathrm{C}(14) & 104.0(2) & \mathrm{O}(20)-\mathrm{Cl}(18)-\mathrm{O}(21) & 113.9(3) \\ \mathrm{S}(10)-\mathrm{C}(11)-\mathrm{N}(12) & 117.9(3) & \mathrm{O}(20)-\mathrm{Cl}(18)-\mathrm{O}(22) & 111.7(3) \\ \mathrm{S}(10)-\mathrm{C}(11)-\mathrm{N}(13) & 120.8(3) & \mathrm{O}(21)-\mathrm{Cl}(18)-\mathrm{O}(22) & 109.1(2) \\ \mathrm{N}(12)-\mathrm{C}(11)-\mathrm{N}(13) & 121.3(4) & & \end{array}$

Table 3. Torsion angles in the macrocyclic ring $\left({ }^{\circ}\right)$

$\begin{array}{lrllr}C^{\prime}(9)-C(1)-O(2)-C(3) & -175.5(3) & C(1)-O(2)-C(3)-C(4) & 179.3(3) \\ O(2)-C(3)-C(4)-O(5) & 63.4(4) & C(3)-C(4)-O(5)-C(6) & -179.5(3) \\ C(4)-O(5)-C(6)-C(7) & 177.3(3) & O(5)-C(6) \cdot C(7) & O(8) & 70.2(4) \\ C(6)-C(7)-O(8)-C(9) & -177.7(3) & C(7)-O(8) C(9) & C^{\prime}(1) & 175.7(3) \\ O(8)-C(9)-C^{\prime}(1)-O^{\prime}(2) & 64.7(4) & & \end{array}$

two hydrogen bonds, one of which is bifurcated. The dimensions of the hydrogen bonds are: $\mathrm{N}(13) \cdots \mathrm{O}^{\prime \prime}(19) 3 \cdot 104$ (5), $\mathrm{N}(13) \cdots \mathrm{O}^{\prime \prime}(21) 3 \cdot 225$ (5), $\mathrm{N}(13) \cdots \mathrm{O}(22) 3.031(5) \AA \AA ; \mathrm{N}(13)-\mathrm{H}(13 B) \cdots \mathrm{O}^{\prime \prime}(19)$ $139(6), \quad \mathrm{N}(13)-\mathrm{H}(13 B) \ldots \mathrm{O}^{\prime \prime}(21) \quad 147$ (6). N(13)$\mathrm{H}(13 A) \cdots \mathrm{O}(22) 139(6)^{\circ}$ (the doubly primed atoms are related to the original ones by the transformation $1-x, 1-y, 1-z$ ). From Table 3 it can be seen that the sequence of torsion angles $(\mathrm{O}-\mathrm{C}$, $\mathrm{C}-\mathrm{C}, \mathrm{C}-\mathrm{O}$ ) in the independent part of the ring is $\mathrm{ag}^{+} \mathrm{aag}^{-} \mathrm{aag}^{+} a$, giving rise to an almost ideal 'crown' conformation with approximate $D_{3 d}$ symmetry. In this conformation the $\mathrm{O}$ atoms lie alternately above and below the mean plane of the ring, making hydrogen bonding to $\mathrm{O}$ atoms, which are next nearest neighbours, possible. The same conformation of the ring has been found in most crystal structures of complexes of 18-crown-6 (Goldberg, 1980). The mean values of the $\mathrm{C}-\mathrm{C}$ bond length $[1.481$ (3) $\AA]$, the $\mathrm{C}-\mathrm{O}$ bond length $[1.422(2) \AA]$, the $\mathrm{O}-\mathrm{C}-\mathrm{C}$ bond angle $\left[109.6(2)^{\circ}\right]$ and $\mathrm{C}-\mathrm{O}-\mathrm{C}$ bond angle $\left[112.3(2)^{\circ}\right]$ compare well with the average values for a number of different 18-crown-6 structures given by Goldberg (1980) $\left(1.495,1.42 \AA, 109.5\right.$ and $112.6^{\circ}$ respectively).

The shortening of the $\mathrm{C}-\mathrm{C}$ bond | single paraffinic C-C bond: 1.541 (3) Å (Kennard, 1962)] is largely, but not completely, due to the neglect of the effect of thermal motion on bond lengths (Maverick, Seiler, Schweizer \& Dunitz, 1980).

\section{References}

Busing. W. R., Martin. K. O. \& Levy. H. A. (1962). ORFLS. Report ORNL-TM-305. Oak Ridge National Laboratory. Tennessee.

Germain, G., Main, P. \& Woolfson, M. M. (1971). Acta Cryst. A27, 368-376.

Goldberg, 1. (1980). The Chemistry of Ethers, Crown Ethers, Hydroxyl Groups and their Sulphur Analogues, Suppl. E1, edited by S. PATAl, pp. 175-213. London: John Wiley.

Harkema, S., van Hummel, G. J., Dahsvatn, K. \& Reinhoudt, D. N. (1981). J. Chem. Soc. Chem. Commun. pp. 368-369.

International Tables for X-ray. Crystallography (1974). Vol. IV. Birmingham: Kynoch Press.

JoHNSON, C. K. (1965). ORTEP. Report ORNL-3794. Oak Ridge National Laboratory. Tennessee.

KenNard, O. (1962). International Tables for X-ray Crystallography. Vol. Ill, p. 276. Birmingham: Kynoch Press.

KNÖChel, A., Kopf, J., Oehler. J. \& Rudolph. G. (1978). J. Chem. Soc. Chem. Commun. pp. 595-596.

Maverick, E.. Seiler, P.. Schweizer, W. B. \& Dunitz. J. D. (1980). Acta Cry'st. B36, 615-620.

Pedersen. C. J. (1971). J. Org. Chem. 36. 1690-1693

Stewart, R. F., Davidson, E. R. \& Simpson. W. T. (1965). J. Chem. Phy's. 42, 3175-3187.

Willis, B. T. M. \& PryoR, A. W. (1975). Thermal Vibrations in Cry'stallography'. pp. 101-102. Cambridge Univ. Press. 